\title{
KEPUASAN MAHASISWA SURABAYA DALAM MENGGUNAKAN MESSAGING APPLICATION (LINE, WHATSAPP, DAN BBM) SURABAYA STUDENT SATISFACTION IN USING THE MESSAGING APPLICATION (LINE, WHATSAPP, AND BBM)
}

\author{
Oleh: \\ Finsensius Yuli Purnama ${ }^{1)}$, Maria Yuliastuti ${ }^{2)}$ \\ Program Studi Ilmu Komunikasi, Fakultas Ilmu Komunikasi, Universitas Katolik Widya \\ Mandala Surabaya \\ E-mail : finsensius@ukwms.ac.id ${ }^{1)}, \underline{\text { maria_yuliastuti@ukwms.ac.id }{ }^{2)}}$
}

\begin{abstract}
Abstrak
Penelitian ini menguji teori uses \& gratifications untuk melakukan tes atas tipologi motif menurut Denis McQuails pada mahasiswa di Surabaya dalam menggunakan messaging application: LINE, WA, dan BBM. Mahasiswa dipilih sebagai subjek penelitian karena secara umummemiliki kemampuan intelektual yang spesifik sehingga penting diteliti bagaimana motif menggunakan aplikasi tersebut pada mahasiswa di Surabaya. Dengan pendekatan penelitian kuantitatif dan metode survey, didapatkan hasil bahwa mahasiswa puas dalam menggunakan aplikasi BBM, WA, maupun LINE. Adapaun urutannya sebagai berikut: WA, LINE, dan terakhir BBM. Berdasarkan analisis data per indikator, BBM hanya memberikan kepuasan pada kebutuhan untuk mendapatkan identitas personal dan hiburan. Di sisi lain, WA dan LINE memberikan kepuasan pada tiga indikator. Masing-masing urut berdasarkan skor paling tinggi, WA memberikan kepuasan pada indikator identitas personal, pemenuhan hiburan, dan informasi. Sedangkan LINE memberikan kepuasan atas identitas personal, informasi, dan hiburan. Persamaan antara penggunaan LINE dan WA adalah mahasiswa tidak puas dalam pemenuhan integrasi dan interaksi sosial.
\end{abstract}

Kata Kunci: Uses \& Gratifications, Gratification Sought, Gratification Obtain, Messaging Application.

\section{PENDAHULUAN}

Teori uses \& gratifications berpandangan bahwa komunikasi (khususnya media massa) tidak mempunyai kekuatan mempengaruhi khalayak, akan tetapi bahwa audience aktif dan bisa mengenali kebutuhannya, serta mengevaluasi media yang dia gunakan. Teori ini berpendapat bahwa khalayak pada dasarnya menggunakan media massa berdasarkan motif-motif tertentu. Media dianggap memenuhi motif khalayak. Jika motif ini terpenuhi maka kebutuhan khalayak akan terpenuhi. (Kriyantono, $2006: 206)$

Menurut Nurudin (2009 : 192) dalam bukunya, teori uses and gratifications lebih menekankan pada pendekatan manusiawi dalam melihat media massa. Artinya, manusia itu mempunyai otonomi, wewenang untuk memperlakukan media. Blumer dan Katz percaya bahwa tidak hanya ada satu jalan bagi khalayak untuk menggunakan media. Sebaliknya, mereka percaya bahwa ada 
banyak alasan khalayak untuk menggunakan media.

Khalayak dianggap secara aktif menggunakan media untuk memenuhi kebutuhannya. Studi dalam bidang ini memusatkan perhatian pada penggunaan (uses) media untuk mendapatkan kepuasan (gratifications) atas kebutuhan seseorang. (Wahyuni, $2014: 28$ )

Media sosial dapat disebut sebagai medium di internet yang memungkinkan pengguna merepresentasikan dirinya maupun berinteraksi, bekerja sama, berbagi, berkomunikasi dengan pengguna lain, dan membentuk ikatan sosial secara virtual (Nasrullah, 2016 : 11)

Dirilis dari techinasia.com (2016) bahwa We Are Social melakukan survey pada tahun 2016 terkait dengan jumlah pengguna media sosial di Indonesia. Tujuh puluh sembilan juta orang atau 30\% dari jumlah penduduk Indonesia, aktif menggunakan media sosial. Dapat dikatakan seperempat atau $25 \%$ dari seluruh total populasi penduduk di Indonesia menggunakan handphone atau smartphone dalam mengakses media sosial.

Teori uses and gratification dikembangkan oleh sekian banyak tokoh yang mengemukakan berbagai motif orang menggunakan media massa. Setidaknya ada tiga tokoh yang mengembangkan tipologi motif tersebut: Rubin (1981),
McQuail et. al (1972), dan Katz et. al (1973).

Semua tipologi motif menggunakan media massa tersebut berangkat dari asumsi bahwa audiens merupakan pribadi yang aktif; dapat mengenali kebutuhannya atas komunikasi massa sekaligus mengevaluasi penggunaannya. Dalam pendekatan ini, audiens tidak lagi menjadi pribadi yang pasif dan hanya menerima pesan komunikasi massa tanpa bisa memilih atau mengevaluasi. Secara lebih spesifik jika motif tersebut terpenuhi, maka kebutuhan individu juga terpenuhi dan akan menimbulkan kepuasan dari pengguna media tersebut. Konsep mengukur kepuasan inilah yang disebut Gratification Sought (GS) dan Gratification Obtained (GO).

Pada pendekatan teori uses \& gratification, gratification sought (GS) merupakan hal yang mendorong khalayak dalam memilih media. Kebanyakan riset uses \& gratification memfokuskan pada GS sebagai variabel independen yang mempengaruhi penggunaan media (Kriyantno, 2006). Kemudian melalui gratification obtained mempertanyakan hal-hal yang khusus mengenai apa saja yang telah diperoleh setelah menggunakan media dengan menyebutkan acara atau rubrik tertentu secara spesifik (Kriyantono, 2006). 
McQuail, Blumler dan Brown (2011), membuat kategori tentang kepuasan yang berkaitan dengan penggunaan media antara lain yaitu: Informasi, Identitas Pribadi, Integrasi dan Interaksi Sosial, dan Hiburan.

Penelitian ini akan menyelidiki motif yang mendorong para mahasiswa di Surabaya dalam menggunakan messaging application: LINE, WA, dan BBM sehingga mereka mendapatkan kepuasan atas messaging application yang mereka gunakan. Berdasarkan situs statista.com, kelompok anak muda usia 17 - 22 tahun adalah kelompok umur yang paling banyak menggunakan aplikasi messenger. Usia tersebut merupakan kelompok usia di level pendidikan mahasiswa. Selain itu, mahasiswa memiliki kemampuan intelektual yang spesifik sehingga penting diteliti bagaimana motif menggunakan aplikasi tersebut pada mahasiswa di Surabaya.

Dirilis dari new media fest (2014) terkait dengan survey yang dilakukan amaliapranata mengenai digital natives di Kota Surabaya yang menggunakan media sosial. Digital natives merupakan sebutan untuk pengguna internet yang lahir di era digital, mereka dengan mudah dapat mempelajari dan menggunakan media. Terhitung di tahun 2017 generasi tertua digital natives telah berusia 38 tahun. Dari hasil survey diketahui bahwa $83,1 \%$ dari digital natives yang berdomisili di kota Surabaya mengakses media sosial Instagram, sedangkan $16,9 \%$ sisanya menggunakan perangkat atau aplikasi media sosial lainnya. Hasil ini didapat dari jumlah 100 sampel masyarakat kota Surabaya yang dilakukan oleh Amaliapranata (2014).

\section{TINJAUAN TEORITIS}

\section{Teori Uses and Gratifications}

Teori uses and gratificiations berfokus pada pada apa yang dilakukan individu terhadap media (West \& Turner, 2010:101). Dimana pada dasarnya teori ini tidak tertarik pada apa yang dilakukan media kepada khalayaknya, tetapi sebaliknya tertarik pada apa yang dilakukan khalayak terhadap media. Teori ini menganggap seseorang aktif karena mereka memiliki kemampuan untuk mempelajari dan mengevaluasi berbagai jenis media untuk mencapai tujuan komunikasi tertentu (West \& Turner, 2010:101).

Diawali dari kebutuhan (need) yang pada dasarnya merupakan awal dari munculnya sikap aktif pada individu. Melalui teori inilah, nantinya dapat diketahui alasan khalayak dalam menggunakan media karena terdapat motif yang mendorong khalayak untuk menggunakan media tersebut. 
Katz, Blumler, dan Gurevitch (dalam West \& Turner 2010:104) menyatakan bahwa terdapat lima asumsi dasar teori uses and gratificiations, di antaranya adalah:

1. Khalayak bersikap aktif dan penggunaan medianya berorientasi pada suatu tujuan tertentu.

2. Inisiatif dalam menghubungkan kepuasan kebutuhan pada pilihan media tertentu terdapat pada anggota khalayak.

3. Media berkompetisi dengan sumber-sumber lain untuk memuaskan kebutuhan anggota khalayak.

4. Anggota khalayak mempunyai cukup kesadaran diri terhadap penggunaan media mereka, minat, dan motif sehingga dapat memberikan sebuah gambaran yang akurat mengenai kegunaan tersebut kepada para peneliti.

5. Penilaian mengenai nilai isi media hanya dapat dinilai oleh anggota khalayak yang mengkonsumsinya.

Lebih lanjut Dennis McQuail, Jay Blumler, dan Joseph Brown (dalam West \& Turner, 2012:105) mengidentifikasi beberapa cara untuk mengklasifikasikan kebutuhan dan kepuasan khalayak yang dapat dipenuhi oleh media. Klasifikasi tersebut antara lain adalah pengalihan (diversion), hubungan personal (personal relationship), identitas personal (personal identity), dan pengawasan (surveillance).

Melalui pernyataan di atas, jelas bahwa khalayak pada dasarnya menggunakan media massa berdasarkan motif-motif tertentu. Sehingga media digunakan sebagai salah satu cara untuk memuaskan kebutuhan khalayak. Pada akhirnya, media yang mampu memenuhi kebutuhan khalayak disebut media yang efektif (Kriyantono, 2012:208).

Melalui bagan tersebut, dapat dilihat dengan jelas awal mulanya berasal dari kebutuhan (need) yang melahirkan motif yang mendasari khalayak untuk menggunakan (uses) sebuah media guna mendapatkan kepuasan (gratification). Philip Palmgreen (dalam Kriyantono, 2012:210) juga mengatakan bahwa khalayak menggunakan media didorong oleh motif-motif tertentu.

Konsep mengukur kepuasan inilah yang disebut Gratification Sought (GS) dan Gratification Obtained (GO). Pada pendekatan teori uses \& gratification, gratification sought (GS) merupakan hal yang mendorong khalayak dalam memilih media. Pada riset ini, Gratification Sought (GS) sebagai variabel independen yang mempengaruhi penggunaan media (Kriyantno, 2006). Kemudian melalui gratification obtained mempertanyakan 
hal-hal yang khusus mengenai apa saja yang telah diperoleh setelah menggunakan media dengan menyebutkan acara atau rubrik tertentu secara spesifik (Kriyantono, 2006).

\section{Gratification Sought (GS)}

Setiap individu dalam menggunakan suatu media digerakkan atau didorong oleh motif-motif tertentu untuk memenuhi kebutuhan dan keinginan (want \& need) tertentu (Kriyantono, 2012:356). Sehingga individu dalam hal ini berusaha untuk memenuhi kebutuhan mereka. Dimana kebutuhan itu sifatnya mutlak harus dipenuhi dalam diri manusia (Kriyantono, 2012:356).

\section{Gratification Obtained (GO)}

Pada teori uses and gratifications, kepuasan yang didapat dikenal dengan konsep gratification obtained. Dalam buku Kriyantono yang berjudul Teknik Riset Komunikasi, merumuskan gratification obtained adalah kepuasan yang nyata yang diperoleh seseorang setelah mengonsumsi media tertentu.

McQuail, Blumler dan Brown, membuat kategori tentang kepuasan yang berkaitan dengan penggunaan media antara lain yaitu :

1. Informasi

(surveillance), merupakan motif individu menggunakan media karena adanya kebutuhan informasi dari sekitar. a. Mencari berita dan kondisi berkaitan dengan lingkungan sekitar.

b. Memuaskan ingin tahu dan minat umum.

c. Belajar, pendidikan sendiri.

2. Identitas personal (personal identity)

a. Menunjang nilai - nilai pribadi.

b. Meningkatkan pemahaman tentang diri sendiri.

c. Menemukan model perilaku.

3. Integrasi (personal relationship)

a. Memperoleh pengetahuan tentang keadaan orang lain.

b. Mengidentifikasi diri dengan orang lain dan meningkatkan rasa memiliki.

c. Memperoleh teman.

d. Menemukan bahan percakapan dan interaksi sosial.

e. Membantu menjalankan peran social.

4. Hiburan (diversion)

a. Melepaskan diri atau teroisah dari permasalahan.

b. Bersantai.

c. Mengisi waktu.

d. Penyaluran emosi. 
Berbeda dengan Blumler yang mengoperasionalkan motif ke dalam tiga orientasi, yaitu : (Rahkmat, 2012:66)

1. Orientasi Kognitif : kebutuhan akan informasi , surveillance, atau explorasi realitas.

2. Orientasi Diversi : kebutuhan akan pelepasan dari tekanan dan kebutuhan akan hiburan.

3. Orientasi Identitas Personal: menggunakan isi media untuk memperkuat/menonjolkan sesuatu yang penting dalam kehidupan atau situasi khalayak sendiri.

McQuail, Blumler, dan Brown (dalam Severin \& Tankard, 2005:356), mengusulkan empat kategori sebagai berikut :

1. Pengalihan : pelarian dari rutinitas dan masalah, pelepasan emosi.

2. Hubungan Personal: manfaat sosial informasi dalam percakapan, pengganti media untuk kepentingan perkawanan.

3. Identitas Pribadi / Psikologi Individu: penguatan nilai atau penambah keyakinan, pemahaman diri, explorasi realitas, $\mathrm{dsb}$.

4. Pengawasan: informasi mengenai hal-hal yang mungkin mempengaruhi seseorang atau akan membantu seseorang melakukan/ menuntaskan sesuatu.
Beberapa kategori yang telah disampaikan diatas, maka penelitian ini akan menggunakan yang paling sesuai, di antaranya adalah:

\section{Informasi}

Meliputi kebutuhan akan berbagai jenis informasi mengenai lingkungan sekitar atau eksplorasi realitas.

2. Identitas Pribadi

Memperkuat dan menonjolkan sesuatu atau situasi yang penting dalam dirinya sendiri.

3. Integrasi dan Interaksi Sosial Berkaitan dengan kelangsungan hubungannya dengan orang lain.

\section{Hiburan}

Membahas kebutuhan individu akan pelepasan dari tekanan dan kebutuhan akan hiburan.

\section{METODE PENELITIAN}

Jenis penelitian yang digunakan dalam penelitian ini adalah jenis penelitian eksplanatif. Jenis penelitian eksplanatif menghubungkan atau mencari sebab akibat antara dua variabel yang diteliti (Kriyantono, 2008).

Penelitian ini menggunakan dua varibel yaitu kepuasan yang dicari (GS) dan kepuasan yang didapat (GO) pendengar radio. Teori uses \& gratification berbicara mengenai bagaimana cara mengukur GS hingga 
muncul kepuasan (GO) pada audiens dalam menggunakan suatu media.

Dimana dalam penelitian ini, motif mahasiswa menggunakan messaging application (BBM, Whatsapp, dan Line). Kepuasan tersebut diukur melalui empat indikator yaitu indikator informasi, indikator identitas pribadi, indikator integrasi dan interaksi sosial dan indikator hiburan.

\section{Definisi Operasional Variabel}

Sesuai dengan teori yang disampaikan oleh McQuail (2011:72), dimana terdapat empat motif dalam penggunaan media, diantaranya adalah motif informasi, motif identitas personal, motif hiburan, juga motif integrasi dan interaksi sosial. Berikut definisi operasional dari masing-masing indikator yang digunakan dalam penelitian ini:

a. Motif Informasi:

Motif Informasi (surveillance), merupakan motif mahasiswa dalam menggunakan messaging application (BBM, Whatsapp, dan Line) karena adanya kebutuhan informasi dari lingkungan sekitar mereka

b. Motif Identitas Personal:

1. Mahasiswa dapat menemukan penunjang nilai-nilai yang berkaitan dengan usia mereka yang masih Remaja
2. Mahasiswa dapat mengidentifikasikan diri dengan nilai-nilai lain dalam muatan media sosial yang mereka akses

3. Mahasiswa memperoleh nilai lebih ketika mengakses media sosial

c. Motif Integrasi dan Interaksi Sosial:

1. Mahasiswa memperoleh pengetahuan yang berkenaan dengan empati sosial yang terjadi di lingkungan mereka.

2. Mahasiswa dapat menemukan bahan percakapan dan interaksi sosial dengan orang lain disekitar, terlebih temanteman sebaya.

3. Keinginan untuk lebih dekat dengan orang lain, khususnya teman sebaya.

\section{d. Motif Hiburan:}

Mahasiswa dapat melepaskan diri sejenak dari masalah yang mereka hadapi

1. Mahasiswa dapat bersantai dan mengisi waktu luang.

2. Mahasiswa dapat mendapatkan hiburan dan kesenangan.

3. Mahasiswa dapat menyalurkan emosi sesaat. 
4. Kepuasan yang didapatkan.

Ada empat kategori dalam penelitian ini adalah

a. Kepuasan Informasi:

Kepuasan Informasi (surveillance), merupakan Kepuasan mahasiswa dalam menggunakan messaging application (BBM, Whatsapp, dan Line) karena adanya kebutuhan informasi dari lingkungan sekitar mereka

1.) Mahasiswa dapat mengetahui berbagai peristiwa dan kondisi yang berkaitan dengan lingkungan masyarakat terdekat dengan mereka dari media sosial yang mereka akses.

2.) Mahasiswa dapat mencari bimbingan menyangkut berbagai masalah yang terjadi pada mereka dari media sosial yang mereka akses.

3.) Mahasiswa dapat mencari bimbingan menyangkut berbagai pendapat dari media sosial yang mereka akses.
4.) Mahasiswa dapat memperoleh rasa nyaman melalui penambahan pengetahuan dari media sosial yang mereka akses.

b. Kepuasan Identitas Personal:

1.) Mahasiswa dapat menemukan penunjang nilai-nilai yang berkaitan dengan usia mereka yang masih Remaja.

2.) Mahasiswa dapat mengidentifikasikan diri dengan nilai-nilai lain dalam muatan media sosial yang mereka akses.

3.) Mahasiswa memperoleh nilai lebih ketika mengakses media sosial.

c. Kepuasan Integrasi dan Interaksi Sosial:

1.) Mahasiswa memperoleh pengetahuan yang berkenaan dengan empati sosial yang terjadi di lingkungan mereka. 
2.) Mahasiswa dapat menemukan bahan percakapan dan interaksi sosial dengan orang lain disekitar, terlebih teman-teman sebaya.

3.) Keinginan untuk lebih dekat dengan orang lain, khususnya teman sebaya.

d. Kepuasan Hiburan:

1.) Mahasiswa dapat melepaskan diri sejenak dari masalah yang mereka hadapi.

2.) Mahasiswa dapat bersantai dan mengisi waktu luang.

3.) Mahasiswa dapat mendapatkan hiburan dan kesenangan.

4.) Mahasiswa dapat menyalurkan emosi sesaat.

\section{Populasi dan Sampel}

Populasi merupakan jumlah keseluruhan dari unit analisa yang ciricirinya akan diduga (Singarimbun, 2006:152). Populasi yang akan diambil dalam penelitian ini adalah masyarakat Surabaya yang berjumlah 3.125.576 jiwa (BPS, 2013).
Melalui jumlah total masyarakat Surabaya tersebut, selanjutnya akan diseleksi kembali sesuai dengan topik penelitian yang akan diambil dalam penelitian ini untuk dijadikan sampel yaitu mahasiswa.

Berikut ini cara penentuan sampel dalam penelitian ini. Penentuan ukuran sampel atau jumlah responden dalam penelitian ini menggunakan penghitungan statisitik yakni dengan menggunakan Rumus Slovin (Kriyantono, 2012:164) berikut:

$n=\frac{\mathrm{N}}{1+\left(\mathrm{Ne}^{2}\right)}$

Keterangan:

n : ukuran sampel

$\mathrm{N} \quad$ : ukuran populasi

e : kelonggaran ketidaktelitian

karena kesalahan pengambilan sampel yang dapat ditolerir, kemudian e ini dikuadratkan.

Di mana dalam penelitian ini, jumlah populasi sebesar 3.125.576 orang. Sehingga dapat dihitung jumlah sampel yang akan digunakan dalam penelitian ini sebagai berikut:

$n=\frac{3125576}{1+\left(3125576 \times 0,1^{2}\right)}$

$n=\frac{3125576}{1+31255,76}$

$n=99,9$ (dibulatkan menjadi 100) 
Pada penelitian ini untuk menentukan jumlah responden dalam penelitian ini, peneliti menggunakan Rumus Slovin dengan asumsi kelonggaran kesalahan sebesar $10 \%$ untuk mendapatkan data yang akurat dengan kesalahan minimum. Melalui perhitungan jumlah sampel yang didapatkan dari perhitungan diatas, maka diperoleh total 100 sampel yang akan digunakan dalam penelitian ini.

Melalui perhitungan jumlah sampel yang didapatkan dari perhitungan diatas, maka diperoleh total 100 sampel yang akan digunakan dalam penelitian ini. Teknik pengambilan sampel dalam penelitian ini menggunakan teknik purposive sampling. Purposive sampling atau sering disebut judgment sampling adalah pemilihan subjek penelitian dengan menentukan terlebih dahulu syarat yang harus dipenuhi agar dapat digunakan sebagai sampel (Silalahi, 2012: 272). Syarat yang harus dipenuhi oleh responden dalam penelitian ini adalah:

1. Mahasiswa aktif di salah satu universitas di Surabaya (dibuktikan dengan KTM)

2. Menggunakan tiga aplikasi Line, Whatsapp, dan BBM sebagai sarana komunikasi.

\section{Teknik Pengumpulan Data dan Uji}

Validitas dan Reliabilitas

Teknik pengumpulan data menggunakan kuesioner sebagai sumber primer dan studi pustaka sebagai sumber sekunder. Data tersebut kemudian diuji validitas dan reliabilitasnya. Uji validitas dan reliabilitas mengikuti kaidah sebagai berikut. Peneliti ini menggunakan program statistik untuk membantu ketika mengolah dan menganalisis data. Langkah-langkah yang akan dilakukan adalah sebagai berikut:

a. Uji validitas dilakukan untuk mengetahui apakah alat ukur yang telah disusun dapat digunakan untuk mengukur apa yang hendak diukur secara tepat.

b. Apabila instrumen tersebut mampu untuk mengukur apa yang diukur, maka disebut valid dan sebaliknya, apabila tidak mampu untuk mengukur apa yang diukur, maka dinyatakan tidak valid (Sudarmanto, 2005).

c. Reliabilitas instrumen menggambarkan pada kemantapan dan keajegan alat ukur yang digunakan. Uji reliabilitas akan dilakukan dengan menggunakan uji coba koefisien reliabilitas internal dari Alpha $(\alpha)$ (Sudarmanto, 2005). 


\section{Teknik Analisis Data}

Penelitian ini akan melakukan beberapa tahapan persiapan data untuk memudahkan proses analisis dan intepretasi hasil yaitu melalui tahapan berikut (Ruslan, 2013:167):

a. Pengeditan (Editing) :

Proses pengecekan dan penyesuaian yang diperlukan terhadap data penelitian yaitu untuk memudahkan proses pemberian kode dan pemrosesan data melalui teknik statistik. Proses editing ini bertujuan untuk menjamin kelengkapan, konsistensi dan kesiapan data dalam proses analisis.

b. Pemberian Kode (Coding) :

Proses identifikasi dan klarifikasi data penelitian ke dalam skor numeric atau karakter simbol-simbol tertentu. Coding bertujuan untuk meningkatkan efisiensi data entry processing ke sistem program komputer.

c. Tabel Frekuensi :

Suatu proses yang hampir serupa dengan tallying yaitu dengan menghitung jawaban yang berasal dari hasil coding. Setelah tahapan-tahapan tersebut dilakukan, peneliti akan melakukan pengolahan data dengan menggunakan bantuan computer statistic yaitu Excel Statistic Analysis dan Statistic Package for
Social Sains (SPSS). Setelah melakukan pengolahan data, akan terlihat kesenjangan kepuasan dari indikator sebagai berikut (Kriyantono, 2008:210):

a. Jika mean skor GS lebih besar dari mean skor GO (mean skor GS > mean skor GO), maka terjadi kesenjangan kepuasan, karena kebutuhan yang di peroleh lebih sedikit dibandingkan dengan kebutuhan yang diinginkan. Media tidak memuaskan khalayaknya.

b. Jika mean skor GS lebih kecil dari mean skor GO (GS < GO). Maka terjadi kesenjangan kepuasan karena kebutuhan yang diperoleh lebih banyak dibandingkan dengan kebutuhan yang diinginkannya. Dengan kata lain media tersebut memuaskan khalayaknya.

\section{HASIL DAN PEMBAHASAN}

\section{Gambaran Umum Subyek Penelitian}

Responden dalam penelitian ini terdiri dari 100 mahasiswa di Surabaya dengan karakteristik yang sama, yakni pernah menggunakan aplikasi messanger. Dapat dilihat pada tabel 4.1 bahwa semua responden memenuhi karakteristik tersebut. 
Tabel 4.1

Karakteristik Responden : Aplikasi Messanger

\begin{tabular}{|c|c|c|}
\hline Iklan & Ya/Tidak & Persentase \\
\hline Pernah Menggunakan Aplikasi Messanger & 100 & 100.0 \\
\hline TOTAL & 100 & 100.0 \\
\hline
\end{tabular}

Sumber : Kuesioner Identitas Responden No 4

Berdasarkan jenis kelamin, pernyataan yang ada di kuesioner responden terbanyak adalah mereka yang berjenis kelamin perempuan. Hal itu dapat dipahami karena secara umum, jumlah populasi menunjukkan bahwa perempuan memiliki jumlah lebih banyak dibanding laki-laki. Tabel 4.2 menunjukkan angka 65 responden merupakan responden dengan jenis kelamin perempuan, dan sisanya berjenis kelamin laki-laki.

Dilihat dari karakteristik usia, responden mahasiswa yang mengisi kuesioner banyak didominasi oleh mereka yang berusia 18 - 20 tahun (67\%). Para mahasiswa ini merupakan mahasiswa tingkat awal (semester $1-6$ ). Sisanya adalah mereka yang berusia 21 - 23 tahun sebanyak 25\%, usia 24 - 26 tahun sebanyak $6 \%$, dan usia di atas 27 tahun (2 responden).

Pada bagian selanjutnya, hasil uji validitas dan reliabilitas atas jawaban responden. Pengujian dilakukan dengan bantuan software SPSS.

\section{Hasil Uji Validitas dan Reliabilitas}

Uji validitas pernyataan bagian tabel 4.2 menunjukkan item-item Gratification Obtain/ Kepuasan adalah valid. Nilai signifikansi untuk koefisien korelasi antara setiap item dengan total item lebih kecil dari taraf signifikansi yang ditetapkan 0,05 yaitu 0.1654.

Nilai koefisien reliabilitas sebesar 0.949 lebih besar dari 0,6 berarti seluruh item tersebut diatas sudah reliable untuk menjelaskan variabel reliabilitas.

\section{Analisis Data}

Berikut ini adalah hasil olah data jawaban para responden mengenai kepuasan mahasiswa Surabaya mengganakan aplikasi BBM, Whatsapp, dan LINE. Analisis data dilakukan dengan melihat angka ekstrim dan trend dari keseluruhan data.

\section{a. Kepuasan Mahasiswa Surabaya Dalam Menggunakan BBM}

Didapatkan dalam menggunakan BBM. Penggunaan BBM sebagai sarana komunikasi menunjukkan data bahwa dari empat pernyataan yang diajukan, kepuasan muncul pada 50\% dari total pernyataan. Dua pernyataan 
yang menunjukkan hasil puas adalah pernyataan 2 dan 4 .

Pernyataan 2 tentang motif dan kepuasan yang didapatkan dalam menguatkan identitas diri melalui BBM menunjukkan bahwa gap antara GS dan GO adalah 0.14.

Sedangkan pernyataan 4 tentang kepuasan dalam mendapatkan hiburan memiliki selisih skor GS dan GO separuh dari pada pertanyaan 2 dengan skor 0.07 .

Tabel 4.2

Tabel Rekapitulasi Kepuasan dalam menggunakan BBM

\begin{tabular}{|c|c|c|c|c|}
\hline Pernyataan & GS & GO & KESENJANGAN & HASIL \\
\hline $\begin{array}{l}\text { Kepuasan } \\
\text { Mahasiswa } \\
\text { Surabaya Untuk } \\
\text { Memperoleh } \\
\text { Informasi Dengan } \\
\text { Menggunakan } \\
\text { Application } \\
\text { Messanging BBM }\end{array}$ & 2,82 & $\begin{array}{c}2,7 \\
0\end{array}$ & $\mathrm{GS}>\mathrm{GO}$ & $\begin{array}{l}\text { TIDAK } \\
\text { PUAS }\end{array}$ \\
\hline $\begin{array}{l}\text { Kepuasan } \\
\text { Mahasiswa } \\
\text { Surabaya Untuk } \\
\text { Memperoleh } \\
\text { Identitas Personal } \\
\text { Dengan } \\
\text { Menggunakan } \\
\text { Application } \\
\text { Messanging BBM }\end{array}$ & 2,50 & $\begin{array}{c}2,6 \\
4\end{array}$ & $\mathrm{GS}<\mathrm{GO}$ & PUAS \\
\hline $\begin{array}{l}\text { Kepuasan } \\
\text { Mahasiswa } \\
\text { Surabaya Untuk } \\
\text { Memperoleh } \\
\text { Integrasi dan } \\
\text { Interaksi Sosial } \\
\text { Dengan } \\
\text { Menggunakan } \\
\text { Application } \\
\text { Messanging BBM }\end{array}$ & 2,92 & $\begin{array}{c}2,8 \\
4\end{array}$ & $\mathrm{GS}>\mathrm{GO}$ & $\begin{array}{c}\text { TIDAK } \\
\text { PUAS }\end{array}$ \\
\hline $\begin{array}{l}\text { Kepuasan } \\
\text { Mahasiswa } \\
\text { Surabaya Untuk } \\
\text { Memperoleh } \\
\text { Hiburan Dengan } \\
\text { Menggunakan } \\
\text { Application } \\
\text { Messanging BBM }\end{array}$ & 2,52 & $\begin{array}{c}2,5 \\
9\end{array}$ & $\mathrm{GS}<\mathrm{GO}$ & PUAS \\
\hline
\end{tabular}

Sumber : Olahan Peneliti 
Dua pernyataan yang menujukkan adanya ketidakpuasan terdapat pada pernyataan 1 dan 3 . Pernyataan 1 tentang kepuasan dalam mendapatkan informasi memiliki gap 0.12 dengan GS lebih besar dari GO. Pernyataan 3 tentang pemenuhan kebutuhan integrasi dan interaksi sosial memiliki gap ketidakpuasan yang lebih tinggi, yakni sebesar 0.08 (GS lebih kecil dari GO).

Berdasarkan tabel tersebut, maka dapat disimpulkan bahwa kepuasan tertinggi dalam menggunakan BBM adalah kebutuhan memperoleh identitas personal, dan pada urutan kedua memperoleh hiburan. Ketidakpuasan paling tinggi adalah kebutuhan untuk memperoleh informasi dan terakhir tidak puas dalam pemenuhan kebutuhan integrasi dan interaksi sosial.

b. Kepuasan Mahasiswa Surabaya Dalam Menggunakan WhatsApp (WA)

Tabel 4.3 menunjukkan data kepuasan dalam menggunakan WA. Dibandingkan dengan penggunaan BBM, WA memiliki kepuasan yang lebih tinggi. Angka menunjukkan bahwa kepuasan muncul pada 3 dari 4 pernyataan. Kepuasan paling tinggi muncul pada pernyataan mengenai kebutuhan identitas personal dengan skor GS dibanding GO 0.16. Kepuasan kedua muncul pada kebutuhan untuk mendapatkan hiburan memiliki skor 0.06 . Kepuasan dengan rangking ketiga muncul pada kebutuhan untuk mendapatkan informasi, yakni dengan skor 0.04 .

Tabel 4.3

Kepuasan dalam Menggunakan WA

\begin{tabular}{|l|c|c|c|c|}
\hline \multicolumn{1}{|c|}{ Pernyataan } & GS & GO & KESENJANGAN & HASIL \\
\hline $\begin{array}{l}\text { Kepuasan } \\
\text { Mahasiswa } \\
\begin{array}{l}\text { Surabaya Untuk } \\
\text { Memperoleh }\end{array}\end{array}$ & 2,4 & 2,52 & GS< GO & PUAS \\
$\begin{array}{l}\text { Informasi Dengan } \\
\text { Menggunakan } \\
\text { Application } \\
\text { Messanging WA }\end{array}$ & 8 & & & \\
\hline $\begin{array}{l}\text { Kepuasan } \\
\text { Mahasiswa }\end{array}$ & 2,3 & 2,51 & GS $<$ GO & PUAS \\
\hline
\end{tabular}




\begin{tabular}{|c|c|c|c|c|}
\hline $\begin{array}{l}\text { Surabaya Untuk } \\
\text { Memperoleh } \\
\text { Identitas Personal } \\
\text { Dengan } \\
\text { Menggunakan } \\
\text { Application } \\
\text { Messanging WA }\end{array}$ & & & & \\
\hline $\begin{array}{lr}\text { Kepuasan } & \\
\text { Mahasiswa } & \\
\text { Surabaya Untuk } \\
\text { Memperoleh } \\
\text { Integrasi dan } \\
\text { Interaksi Sosial } \\
\text { Dengan } \\
\text { Menggunakan } \\
\text { Application } \\
\text { Messanging WA }\end{array}$ & $\begin{array}{c}2,7 \\
6\end{array}$ & 2,73 & $\mathrm{GS}>\mathrm{GO}$ & $\begin{array}{l}\text { TIDAK } \\
\text { PUAS }\end{array}$ \\
\hline $\begin{array}{l}\text { Kepuasan } \\
\text { Mahasiswa } \\
\text { Surabaya Untuk } \\
\text { Memperoleh } \\
\text { Hiburan Dengan } \\
\text { Menggunakan } \\
\text { Application } \\
\text { Messanging WA }\end{array}$ & $\begin{array}{c}2,5 \\
1\end{array}$ & 2,57 & $\mathrm{GS}<\mathrm{GO}$ & PUAS \\
\hline
\end{tabular}

kebutuhan untuk memperoleh

Tabel 4.4 menunjukkan integrasi dan interaksi sosial tidak dapat dipenuhi. Skor GS dibanding GO menunjukkan angka 0.03 dengan angka GS lebih besar dari pada GO. Dengan demikian dapat disimpulkan bahwa mahasiswa tidak puas dalam menggunakan WA untuk memenuhi kebutuhan tersebut. hasil survey mengenai kepuasan mahasiswa dalam menggunakan aplikasi LINE. Secara umum terdapat hasil yang sama dengan kepuasan mahasiswa dalam menggunakan WA. Pernyataan 1,2, dan 4 menunjukkan hasil puas. Akan tetapi, pada pernyataan 3 mahasiswa menyatakan tidak puas atas penggunaan LINE. 
Tabel 4.4

Kepuasan Mahasiswa dalam Menggunakan LINE

\begin{tabular}{|c|c|c|c|c|}
\hline Pernyataan & GS & GO & KESENJANGAN & HASIL \\
\hline $\begin{array}{lr}\text { Kepuasan } & \text { Mahasiswa } \\
\text { Surabaya r Untuk } \\
\text { Memperoleh Informasi } \\
\text { Dengan Menggunakan } \\
\text { Application } \\
\text { Messanging LINE }\end{array}$ & 3,07 & 3,09 & $\mathrm{GS}<\mathrm{GO}$ & PUAS \\
\hline $\begin{array}{lr}\text { Kepuasan } & \text { Mahasiswa } \\
\text { Surabaya } & \text { Untuk } \\
\text { Memperoleh } & \text { Identitas } \\
\text { Personal } & \text { Dengan } \\
\text { Menggunakan } \\
\text { Application } \\
\text { Messanging LINE } \\
\end{array}$ & 2,82 & 2,86 & $\mathrm{GS}<\mathrm{GO}$ & PUAS \\
\hline $\begin{array}{lr}\text { Kepuasan } & \text { Mahasiswa } \\
\text { Surabaya } & \text { Untuk } \\
\text { Memperoleh Integrasi } \\
\text { dan Interaksi Sosial } \\
\text { Dengan Menggunakan } \\
\text { Application } \\
\text { Messanging LINE } \\
\end{array}$ & 3,30 & 3,26 & GS> GO & $\begin{array}{l}\text { TIDAK } \\
\text { PUAS }\end{array}$ \\
\hline $\begin{array}{lr}\text { Kepuasan } & \text { Mahasiswa } \\
\text { Surabaya } & \text { Untuk } \\
\text { Memperoleh Hiburan } \\
\text { Dengan Menggunakan } \\
\text { Application } \\
\text { Messanging LINE }\end{array}$ & 3,00 & 3,01 & $\mathrm{GS}<\mathrm{GO}$ & PUAS \\
\hline
\end{tabular}

Kepuasan tertinggi pada

mahasiswa dalam menggunakan

LINE adalah dalam memenuhi

kebutuhan untuk memperoleh identitas personal. Gap antara GS dengan GO dengan skor 0.04 menjadi skor kepuasan tertinggi dalam menggunakan LINE.

Pernyataan kedua yang
memiliki hasil puas dalam
menggunakan LINE adalah dalam
memenuhi kebutuhan untuk
memperoleh informasi. Pernyataan

1 ini memiliki skor yang 0.02 dengan GO lebih besar dari GS.

Ketiga, pemenuhan kebutuhan mahasiswa utnuk memperoleh hiburan dalam menggunakan LINE memiliki hasil puas dengan skor 0.01. Skor tersebut menunjukkan hasil bahwa GS lebih kecil dari GO.

Pernyataan yang menunjukkan hasil tidak puas muncul pada pemenuhan kebutuhan akan informasi. LINE bagi mahasiswa tidak memberikan 
pemenuhan kebutuhan untuk

memberikan informasi yang

dibutuhkan bagi mahasiswa. Skor

ketidakpuasan berada pada angka

0.04 dengan skor GS lebih besar dari GO.

d. Kepuasan Mahasiswa Surabaya dalam Menggunakan BBM, WA, dan LINE

Pada bagian terakhir ini, tabel 4.5 menunjukkan bahwa secara keseluruhan, mahasiswa puas dalam mengunakan aplikasi BBM, WA, dan LINE. Indikator yang digunakan adalah sebagai berikut:

Jika mean skor (rata-rata skor) GS lebih besar dari mean skor GO (mean skor GS > mean skor GO), maka terjadi kesenjangan kepuasan, karena kebutuhan yang diperoleh lebih sedikit dibandingkan dengan kebutuhan yang diinginkan. Media tidak memuaskan khalayaknya.
Jika mean skor GS sama dengan mean skor $\mathrm{G})(\mathrm{GS}=\mathrm{GO})$ maka tidak terjadi kesenjangan kepuasan karena jumlah kebutuhan yang diinginkan semuanya terpenuhi.

Jika mean skor GS lebih kecil dari mean skor GO (GS < GO) maka terjadi kesenjangn kepuasan karena kebutuhan yang diperoleh lebih banyak dibandingkan dengan kenutuhan yang diinginkan. Dengan kata lain bahwa media tersebut memuaskan khalayaknya.

Berdasarkan tabel 4.5, kepuasan tertinggi ada pada penggunaan aplikasi WA. Mean skor GS dan GO pada WA adalah 0.0575. Selain itu, dilihat dari kepuasan pada 4 indikator juga menunjukkan bahwa penggunaan WA memiliki kepuasan pada 3 indikator.

Tabel. 4.5

Tabel Kepuasan Penggunaan BBM, WA, dan LINE pada Mahasiswa

\begin{tabular}{|c|c|c|}
\hline $\begin{array}{c}\text { Application } \\
\text { Messanging }\end{array}$ & $\begin{array}{c}\text { MEAN SKOR } \\
\text { GS dan GO }\end{array}$ & HASIL \\
\hline BBM & 0,0025 & PUAS \\
\hline WA & 0,0575 & PUAS \\
\hline LINE & 0,0075 & PUAS \\
\hline
\end{tabular}

Sumber: olahan peneliti 
Kepuasan kedua tertinggi ada pada pengguna aplikasi LINE. Mean skor GS dan GO pada penggunaan LINE ada pada skor 0.0075. Secara signifikan angka tersebut berada jauh di bawah mean skor penggunaan WA. Pada urutan terakhir, kepuasan paling rendah ada pada penggunaan BBM. Mean skor pada penggunaan BBM adalah 0.0025 .

\section{PENUTUP}

Berdasarkan hasil penelitian ini, maka dapat disimpulkan bahwa mahasiswa puas dalam menggunakan aplikasi BBM, WA, maupun LINE. Kepuasan tertinggi ada pada penggunaan aplikasi WA. Kepuasan kedua tertinggi ada pada pengguna aplikasi LINE. Pada urutan terakhir, kepuasan paling rendah ada pada penggunaan BBM.

Berdasarkan analisis data per indikator, BBM hanya memberikan kepuasan pada kebutuhan untuk mendapatkan identitas personal dan hiburan. Di sisi lain, WA dan LINE memberikan kepuasan pada tiga indikator. Masing-masing urut berdasarkan skor paling tinggi, WA memberikan kepuasan pada indikator identitas personal, pemenuhan hiburan, dan informasi. Sedangkan LINE memberikan kepuasan atas identitas personal, informasi, dan hiburan. Persamaan antara penggunaan LINE dan WA adalah mahasiswa tidak puas dalam pemenuhan integrasi dan interaksi sosial.

\section{DAFTAR PUSTAKA}

Ardianto. Elvinaro. 2005. Komunikasi massa : Suatu Pengantar. Bandung : Simbiosa Rekatama Media

Budiargo, Dian. 2015. Berkomunikasi Ala Net Generation. Jakarta : Elex Media Komputindo

Kriyantono, Rachmat. 2006. Teknis Praktis Riset Komunikasi. Jakarta : Kencana

2012. Teknik

Praktis : Riset Komunikasi (edisi pertama, cetakan ke-6). Jakarta : Kencana.

McQuail, D. 2011. Teori Komunikasi Massa (edisi 6, buku 2). Jakarta : Salemba Humanika.

Nasrullah, Rulli. 2016. Media Sosial : Perspektif Komunikasi, Budaya, Dan Sosioteknologi. Bandung : Simbiosa Rekatama Media

Nurudin. 2009. Pengantar Komunikasi Massa. Jakarta : PT RajaGrafindo Persada

Rahkmat, J. 2012. Metode Penelitian Komunikasi : Dilengkapi Contoh Analisis Statistik. Bandung : PT Remaja Rosdakarya. 
Severin, W., \& Tankard, J. 2005. Teori Komunikasi : Sejarah, Metode, dan Terapan di Dalam Media Massa (edisi 5). Jakarta : Kencana.

Silalahi, Ulber. 2012. Metode Penelitian Sosial. Bandung: PT. Refika Aditama

Singarimbun, Masri. 2006. Metode Penelititan Survei. Jakarta: LP3S

Sudarmanto, R.Gunawan. 2005. Analisis Regresi Linear Ganda dengan SPSS. Yogyakarta: Graha Ilmu.

West, R., \& Turner,L. 2010. Pengantar Teori Komunikasi : Analisis dan Aplikasi (edisi ketiga). Jakarta : Salemba Humanika.

\section{Jurnal :}

Whitting, Anita \& William, David. 2013. Why People Use Social Media: A Uses and Gratifications Approach. Emerald Group Publishing Limited

\section{Internet / Web :}

https://amaliapranata.carbonmade.com diakses pada tanggal 12 Maret 2017 pukul 13.39 WIB www.techinasia.com diakses pada tanggal 7 Februari 2017 pukul 12.07 WIB https://bps.go.id diakses pada tanggal 11 Maret 2017 pukul 13.46 WIB http://statistik.kominfo.go.id diakses pada tanggal 11 Maret 2017 pukul 22.30 WIB 